\title{
Proposal for integrated analysis of public health emergencies involving arboviruses: the case of the Zika virus in Brazil
}

\author{
Proposta de análise integrada de emergências em saúde pública por \\ arboviroses: o caso do Zika vírus no Brasil
}

\author{
Vera Lucia Edais Pepe', Mariana Vercesi de Albuquerque', Claudia Garcia Serpa Osorio-de- \\ Castro', Claudia Cristina de Aguiar Pereira', Catia Verônica dos Santos Oliveira', Lenice Gnocchi \\ da Costa Reis', Carla de Barros Reis', Henrique Sant'Anna Dias', Elaine Silva Miranda²
}

DOI: 10.1590/0103-11042020E205

\begin{abstract}
The change in the pattern of occurrence of microcephaly associated with Zika virus infection in pregnant women in Brazil resulted in the declaration of a Public Health Emergency of National and International Concern. Coordinated and inter-sector efforts were required, but there were not always effective responses or preparation of the affected populations. The Zika epidemic impacted public policies, including health policy, both in scientific research, proposals for control measures, diagnosis, prevention, and treatment. The study aimed to propose an integrated analysis for the approach to future health emergencies, with a focus on arboviral infections. Based on the Brazilian experience with the Zika epidemic and the related literature, the analysis links four dimensions: vulnerabilities and risk; the population's socioeconomic conditions and impacts; development and use of technologies and research; and the health system's response and reprogramming. The aim is to allow specific research focuses to measure the possible outcomes and generate new evidence on the epidemic's effect on health systems. Scientific knowledge and its gaps are the main integrating elements in these analytic dimensions, aimed at contributing with a more timely and effective response in future emergencies. Besides the acquired knowledge, it is necessary to add capacity to confront future emergencies related to arbovirus epidemics.
\end{abstract}

KEYWORDS Zika virus. Arbovirus infections. Disaster vulnerability. Disaster emergencies. Health systems.

1Fundação Oswaldo Cruz (Fiocruz), Escola Nacional de Saúde Pública Sergio Arouca (Ensp) - Rio de Janeiro (RJ), Brasil. verapepe@ensp.fiocruz.br

2 Universidade Federal Fluminense (UFF), Faculdade de Farmácia Niterói (RJ), Brasil.
RESUMO A mudança no padrão de ocorrência da microcefalia associada à infecção pelo Zika Vírus em gestantes no Brasil resultou na decretação de emergência em saúde pública de importância nacional e internacional. Esforços coordenados e multisetoriais foram demandados, mas nem sempre houve respostas efetivas ou preparação das populações afetadas. A epidemia de Zika repercutiu nas políticas públicas, incluindo a de saúde, seja na investigação científica, seja na proposição de medidas de controle, diagnóstico, prevenção e tratamento. Objetivou-se apresentar proposta de análise integrada para abordagem de futuras emergências sanitárias com foco nas arboviroses. Partindo da experiência brasileira da epidemia e literatura relacionada, articularam-se quatro dimensões: vulnerabilidades e risco; condições e impactos socioeconômicos na população; desenvolvimento e emprego de tecnologias e pesquisas; e resposta e reprogramação do sistema de saúde. Pretende-se viabilizar loci específicos de investigação, para mensuração de possíveis desfechos e geração de novas evidências sobre os efeitos da epidemia nos sistemas de saúde. O conhecimento científico e suas lacunas são considerados os principais elementos integradores dessas dimensões analíticas, de forma a contribuir com resposta mais oportuna e efetiva em futuras emergências. Além do conhecimento adquirido, faz-se necessário agregar capacidade de enfrentar futuras emergências relacionadas com as epidemias de arboviroses.

PALAVRAS-CHAVE Zika vírus. Infecções por arbovírus. Vulnerabilidade a desastres. Emergências em desastres. Sistemas de saúde. 


\section{Introduction}

Arboviral diseases are viral infections with part of their reproductive and transmission cycle involving hematophagous insects. These diseases have become increasingly important due to the disordered growth and occupation of cities, globalization, and climate changes. The response to arbovirus epidemics has challenged public health in numerous ways, due to the wide range of etiological agents with different and sometimes severe clinical manifestations, difficulties in vector control, lack of effective vaccines and treatments, and the impact on populations already exposed to precarious living conditions $\mathbf{1}^{\mathbf{1}} \mathbf{2}$.

In 2015, the detection of a change in the pattern of occurrence of microcephaly in newborn infants, associated with Zika virus infection in pregnant women, sparked concerns due to the epidemic pattern. Brazil declared a national health emergency in November that same year ${ }^{\mathbf{3}, 4}$, followed by the declaration of a Public Health Emergency of International Concern (PHEIC) by the World Health Organization (WHO) in February $2016^{5-7}$. In the last four years, a large body of evidence has emerged on the epidemic, the virus and its effects, detection, clinical forms, control of transmission, and identification and treatment of different manifestations of the Congenital Zika Virus Syndrome (CZVS), which includes ocular, auditory, and motor lesions and cognitive alterations, even in cases without microcephaly.

Public Health Emergencies (PHEs) and disasters, whether natural or manmade, are caused by an 'initiating' and overwhelming event. Depending on the characteristics of the populations and places and the capacity to respond to and confront these events, they can cause considerable damage. In addition to the material damage and loss of lives, there are temporary or permanent consequences in various areas of society, including the economy and health ${ }^{5}$. The populations and places affected by PHEs are not always prepared or effectively equipped to deal with them.

Such events require combined, coordinated, and multisector efforts by different stakeholders from a local, regional, national, and global perspective ${ }^{5}$. This understanding provides the basis for Brazil's health legislation, given its importance for improving the health system's response to the PHE in the country and its impacts $^{8}$. The characteristics and effects of the Zika virus (ZIKV) epidemic have direct impacts on the development of public policies, including health policy, with a view towards investigation and proposal of diagnostic and control measures, as well as the prevention and treatment of its consequences.

In addition to the knowledge acquired in the context of the epidemic, progress is needed on topics that add capacity to confront future emergencies. Institutions need to consolidate lessons to improve the response, emphasizing conditions of vulnerability and risk, inequality and inequity in care, social rights of families and affected individuals, forms of government action in emergencies, and challenges for inter-sector action.

Based on the literature, especially that produced on the ZIKV epidemic in Brazil, the objective here is to present a proposal for integrated analysis of health emergencies related to arboviral infections, linking four dimensions. The first relates to preparedness, considering vulnerabilities and risks from the perspective of the occurrence of disasters. The second considers socioeconomic conditions, especially poverty as an important conditioning factor for the epidemic's effects. The third dimension involves studies and innovation and use of technologies, important integration between health and the other social sectors involved in scientific and technological development. The fourth and final dimension relates to the health system's response and reprogramming, considering its institutional capacity in the management of health emergencies, 
emphasizing public policy development and interaction and the analysis, action, and reorganization of the health services system for dealing with the epidemic.

The assumption is that in future health emergencies, the health system can build and implement a more timely and effective response based on these elements and the experiences and lessons from previous events.

\section{Characterization of vulnerabilities and risks}

Poor populations are usually at increased risk in disasters and health emergencies ${ }^{9}$, as evidenced during the Zika epidemic. Specific population groups such as women and children are among the most vulnerable and require special attention and priority care ${ }^{10}$. Vulnerability, and in this specific case the social vulnerability of these groups, results directly from the social structure and its consequences, such as inequalities in income, housing, and sanitation, access to the health system and healthcare, and differences in social empowerment. These differences ultimately generate unequal exposure to risks ${ }^{11}$.

The Zika virus epidemic began in the Northeast, the region of Brazil with populations living under precarious housing and sanitation conditions. The Northeast concentrated the largest number of cases of microcephaly ${ }^{\mathbf{1 2}}$, and during the period close to the ZIKV epidemic (2013-2015), the region experienced other health emergencies including syphilis ${ }^{\mathbf{1 3}}$ and measles, the latter especially in the states of Pernambuco and Ceará ${ }^{14}$. Other arboviral infections such as dengue and chikungunya were also plaguing the Northeast at the same time ${ }^{\mathbf{1 5}}$.

The relationship between these events and their determinants and contributing factors has not been fully elucidated, nor have the impacts of the ZIKV epidemic been fully explained. However, evidence suggests that the most vulnerable population was the same. In addition, the role of vaccination coverage and cross-protection with other arboviral infections is still under investigation. There are doubts on the epidemic's possible resurgence in terms of its magnitude or form ${ }^{16}$.

Episodes of the epidemic in other countries did not display the same magnitude or severity as in Brazil. The limited knowledge of the disease in society, the scientific community, and sectors involved in healthcare provision and social support hindered a timely response. Health professionals, who make the link between this knowledge 'repository' and the population through healthcare, also found themselves in contradictory situations. There was no preparation, since until then the specific risk related to the consequences of ZIKV was basically unknown. The determinants of social vulnerability, in addition to controversies on the causal agent and microcephaly, compromised the clear communication of risk and its direct mitigation ${ }^{\mathbf{1 7}}$.

At the start of the outbreak, important data that could have detected and characterized the event and its risks were not completely available. For example, data on microcephaly in Brazil were quite limited at the time. The increase of more than tenfold in microcephaly cases recorded at the height of the epidemic may also have been due to other causes ${ }^{17}$, as evidenced by the surge in notifications, many of which unrelated to Zika. The Zika epidemic showed that in the heat of the events, urgent and recurrent needs of the affected population groups came to the surface. The identification of vulnerable groups and the prioritization of care and preventive measures for this population in Brazil proved to be insufficient ${ }^{\mathbf{1 2}}$.

Research projects with participation by human subjects must respect their dignity and comply with the purposes of scientific research. Research in health emergencies and disasters has sparked heated ethical debates. The Zika epidemic led to a 
considerable influx of Brazilian and international research projects and research$\mathrm{ers}^{\mathbf{1 8}}$. The expectation was that these studies would always be based on the best conduct in relation to the affected individuals and their families, since they are the ones most susceptible to potential excesses or improprieties in conducting the research. Therefore, there is a valid concern over studies in the populations most vulnerable to ZIKV ${ }^{19}$.

The health sector comes under especially heavy demand during emergencies. It should be prepared to meet the needs of groups with increased social, physical, environmental, and economic vulnerabilities. It is the scientific community's duty to develop and propose risk-reduction measures and strategies, not only for the future, but also for currently affected populations ${ }^{20}$. What have we learned about risk reduction from the Zika epidemic? Are the lessons only applicable to this emergency, or can they be extrapolated to other emergencies? The preparedness involves a framework of measures and policies that transcends the current possibilities. The affected communities and those remaining in situations of vulnerability are not prepared. Only a small group of affected mothers and children are able to react, based on their conditions of resilience, expressed in the capacity for organization of networks and ties of solidarity.

\section{Socioeconomic conditions and impacts of families of children affected by the Zika epidemic}

The ZIKV epidemic was profoundly related to the affected individuals' socioeconomic conditions ${ }^{\mathbf{1 8}, \mathbf{2 1}}$. While low income and schooling made the individuals more vulnerable in an epidemic context, these same individuals were affected unequally, with implications for households, families, and the job market.
Zika virus infection can result in the birth of children with CZVS, with irreversible and chronic outcomes for their health, including high morbidity 22,23 .

From the microeconomic point of view, the birth of a child with CZVS is directly associated with the risk of impoverishment, imposing limitations on the possibilities for consumption, education, leisure, and work in the present and future, besides reducing the quality of life 24-27. The growth of children with CZVS creates needs for attention and care by the families, especially the mothers, who need to dedicate themselves to daily care and take the children to the health services they need ${ }^{\mathbf{2}}$.

At the household and family level, this negative shock on health creates changes in the capacity for obtaining income and in spending patterns. Economic consequences include direct and indirect costs, such as financial expenditures, sacrificing hours otherwise dedicated to paid work, and time spent caring for the child, forcing the family to create strategies to deal with the new situation. Such strategies may be substituting work at home and away, exhausting their savings and investments, selling assets, and taking out loans, among others. This dynamic may result in a poverty trap for individuals and families $\mathbf{2 4 , 2 6 , 2 9}$.

In all these scenarios, an increase in the poverty level can be expected, jeopardizing the formation of physical, human, and financial capital in the affected families. Depending on the severity of the disease, the effects can be intergenerational, with impacts on the level of future socioeconomic development of individuals, families, and communities ${ }^{30}$. For example, when children with CZVS reach school age, the school system needs to adapt to receive and teach them according to their cognitive and learning capacities ${ }^{\mathbf{3 1} 32}$. There may also be less interest in providing incentives in education, given the impairment to their life expectations and quality of life and thus their acquisition of knowledge and skills ${ }^{33}$.

Understanding the affected households' economic dynamics is important, especially to 
measure the real economic consequences of CZVS. To estimate the total costs for society, it is important not only to understand the perspective of the Unified Health System (SUS), but to consider all sectors affected ${ }^{\mathbf{3 4}}$. The families' perspective is key to this expanded perception.

The medical and non-medical costs have implications for the affected persons' financial protection and vulnerability, especially concerning the direct out-of-pocket expenditures that can perpetuate place lead individuals in situations of poverty and a continuous cycle of disease and poverty ${ }^{29}$, especially since CZVS is a chronic disease ${ }^{25}$. Despite the relevance of these costs for the individuals' and families' well-being, there is little empirical evidence at the household level on the burden of chronic diseases, which is vital for the elaboration of public policies ${ }^{\mathbf{2 4}}$. For example, transportation costs to reach health services account for a major share of total health expenditures ${ }^{35,36}$, but they need to be measured. The same is true for expenditures with food and lodging when accessing healthcare, which also need to be considered $^{29}$.

Families may also incur indirect costs, or those related to loss of productivity in the job market resulting from morbidity and premature mortality associated with the illness. CZVS can affect the daily lives of the children's mothers, fathers, and other family members, decreasing the quality and amount of time for work and leisure.

Measuring the impacts of the Zika epidemic along a timeline, some evidence suggests the generation of considerable economic burden in both the short and long term. An impact assessment study by the United Nations Development Program (UNDP) to analyze data for some Latin American and Caribbean countries estimated that the total costs of Zika in the region are similar to the costs of the dengue epidemic ${ }^{37}$. The decrease in international and domestic tourism revenues and the direct costs with diagnosis and treatment account for the main short-term costs, that is, those tabulated during the epidemic itself. From 2015 to 2017, the estimated burden ranged from US\$ 7 billion to US\$ 18 billion in Northeast Brazil. Although the poorer countries were more heavily affected - considering the costs as a proportion of Gross Domestic Product (GDP) -, Brazil suffered the heaviest absolute burden of shortterm costs due to the higher incidence of cases associated with congenital conditions. Meanwhile, the long-term costs - which consider all the costs incurred from the onset of the epidemic through the estimated life expectancy of the cohort of individuals affected by the epidemic - are mostly represented by the direct and indirect costs associated with microcephaly and Guillain-Barré syndrome. For caregivers of children with CZVS, most of whom are adolescent and young adult women, the loss of productivity from being forced to leave the job market and/or drop out of school further aggravates their cycle of poverty. For children with CZVS, the costs involve lifetime loss of productivity, specific healthcare needs, homecare, education, and transportation. The neurocognitive disorders already present at birth are expected to persist throughout life, resulting in delays in neurological and psychomotor development through problems with balance and coordination, seizures, irritability, and difficulties swallowing and speaking, in addition to visual and auditory problems ${ }^{38}$. The predicted total long-term costs of these conditions can reach US\$ 29 billion and US\$ 10 billion, respective$1 y^{37}$. These numbers represent the epidemic's enormous economic impact for society.

\section{Development and use of technologies and research}

The ZIKV epidemic also had repercussions on scientific and technological development, keeping in mind the need for progress with knowledge and the use of technologies, 
including studies on the organization of existing knowledge on arboviral infections and studies needed to fill some gaps. Partnerships were established with international institutions, facilitated by declaration of the PHEIC, which required coordinated action for research and development of new technologies to confront the epidemic ${ }^{39}$.

At the government level, the epidemic oriented the definition of calls for scientific and technological research projects involving Brazilian government ministries and research funding agencies, targeted among others to immunology and virology, new diagnostic and promotion/prevention technologies; vector control strategies; social technologies and innovation in environmental and health education; innovation in health services and sanitation management and public policies and epidemiology and health surveillance ${ }^{40}$. Research and the development of new technologies have focused on diagnostic, therapeutic, and prevention technologies as well as on vector control.

Diagnostic technologies include diagnosis of the disease and identification of complications of CZVS. The challenge has been to obtain tests capable of diagnosing specific arboviral infections, allowing identification of cases of each of the infections and of individuals with more than one infection, all of which is essential for measuring each arboviral infection's magnitude, estimating their transcendence, and understanding the effects of comorbid infections in the same individual ${ }^{\mathbf{4 1}, \mathbf{4 2}}$. Access to the diagnostic technologies for ZIKV complications is a persistent challenge, because access to medium and high complexity is a bottleneck in the Brazilian health system ${ }^{\mathbf{4 3}}$. Late diagnosis or late or discontinued treatment, especially in infants, can hinder the achievement of potential development or lead to setbacks in the health situation. Guaranteeing timely access to the existing diagnostic and therapeutic resources is essential for reducing negative impacts ${ }^{44}$.
Vaccines and vector control strategies are important technologies for prevention and control45,46. Some 40 to 60 institutions in the world have various strategies for vaccine development: inactivated viruses, virus-like particles, and vaccines with recombinant DNA viruses ${ }^{45}$. However, to date there is no vaccine available on the market. Animal studies have indicated the possibility that the yellow fever vaccine has some protective effect against ZIKV, potentially reducing the viral load in the brain and the neurological effects of the virus ${ }^{47,48}$.

The vector control strategies include known technologies used for dengue, such as educational activities, larval index rapid assays (LIRAs) for Aedes aegypti, larvicides, and traps to reduce and eliminate the mosquito population ${ }^{41}$. More integrated and 'intelligent' information systems that use geospatial technologies and computational models improve the monitoring and control of the Aedes aegypti population as well as the understanding and prediction of arboviral infections ${ }^{49}$.

New vector control technologies include manipulation of the mosquito to produce genetically modified sterile mosquitos, mosquitos carrying the Wolbachia bacteria, and mosquitos spreading the pyriproxyfen pesticide. There are also new traps like the ovitrap for monitoring mosquito infestation ${ }^{41}$. One government measure for prevention has been the use of repellents, and new formulations are under development, such as the use of nanotechnology, to decrease their toxicity ${ }^{50}$. Studies are evaluating the efficacy of clothing and bed nets impregnated with repellent to protect against mosquito bites ${ }^{\mathbf{5 1}}$.

One of the challenges for therapeutic technologies is the discovery of a specific treatment for ZIKV infection. Several in vitro and in vivo studies are under development on the use of drugs and substances already approved by regulatory agencies for other therapeutic indications. For example, sofosbuvir, interferon and other 
polymerase inhibitors, erythrosine $\mathrm{B}$, and chloroquine ${ }^{52-55}$. One recent unusual aspect is the investigation of ZIKV itself as treatment for glioblastoma, a severe and uncurable brain tumor. That is, use of the virus as a therapeutic technology 48 .

Technologies to treat CZVS feature a wide range focused on rehabilitation and prevention of disabilities and sequelae according to case-by-case needs, such as braces, prostheses, and walking/movement aids. New educational and communications technologies in health are being developed, such as courses, training, workshops, booklets, folders, videos, games, apps, and websites for health professionals, families, teachers, and others ${ }^{56}$.

\section{Healthcare systems' response and reprogramming of health services}

The uncertainties and pressures for the production of evidence on Zika pose several challenges for healthcare systems. A plan for response by the WHO in 2016 was followed by a global race to structure rapid responses in reprogramming, aimed at case detection, control of the infection, and treatment of the population with the infection or at risk $\mathbf{7 5 7 , 5 8}$.

The emergency response requires attention to the persons and places at risk ${ }^{59}$ and the different conceptions and definitions of health rights in each country, with variations in the safeguards and universal application. Even in countries with universal health systems, there is some degree of inequality and limitations to the scope of such rights, influencing the capacity for response and reprogramming. The political and institutional configurations of health systems in terms of their roles, responsibilities, healthcare models, regulation, and financing also condition the responses to emergencies and demands. This is further complexified by the different time frames between the production of evidence, establishment of consensuses concerning their social importance in dealing with the infection, and public decisions on the elaboration of responses.

Another important aspect is the involvement of Brazilian and international institutions in science, technology, and innovation in the formulation and implementation of public policies. Government measures should also be oriented by the tacit knowledge from experience with the epidemic and its repercussions ${ }^{60}$.

In Brazil, the epicenter of the ZIKV epidemic, the development of responses combined the recovery of known approaches alongside new forms of intervention. There was a broad range of initiatives, including vector control, risk prevention, integration of surveillance and healthcare systems, intergovernmental coordination, intra- and inter-sector linkage, communications, information, and notification, professional training, and the development of diagnostic and therapeutic protocols ${ }^{39}$.

The control and surveillance systems revealed the need to improve communications during emergencies, both in the health system and for the population, particularly the population affected by the infection and at risk. The relevance of Health Information Systems (HIS) has been emphasized to guarantee data access to support public policies, with special emphasis on strategies for data protection, monitoring, safety, and security $^{61}$. Meanwhile, underutilization of HIS has been a barrier to confronting Zika and other arboviral infections ${ }^{62}$.

Measures to strengthen family planning in Brazil were influenced by international recommendations on postponing pregnancy and expanding access to contraceptive methods in the epidemic's context. However, it is necessary to discuss its limits and effectiveness in reducing ZIKV infection ${ }^{63-65}$. Studies in Latin America and the Caribbean point 
to the low use and availability of intrauterine devices, indicating the need to review government policies to ensure the supply to populations at risk and with greater vulnerability to Zika66.

The discussion on the expansion of legal permission for termination of pregnancy under any circumstances and the identification of barriers to access contraceptive methods resulting from the prevailing policy and its scope were key issues during the public health emergency ${ }^{67-70}$. In addition, wide access to the services and products related to reproductive health requires quality information on the risks and consequences of infection and the available technologies, thereby increasing women's decision-making capacity ${ }^{\mathbf{7}}$.

Concerning the reorganization of prenatal care, the reduction in the odds of infection during pregnancy depends on progress in the establishment of protocols applied to health services to guarantee universal testing for ZIKV. Public health emergencies call for protocols to supply blood products with guaranteed availability, as well as the adoption of complementary safety measures for blood donation procedures ${ }^{\mathbf{7 2}, 73}$.

The effectiveness and follow-up of children's developmental problems after birth depended on the comprehensive supply of cranial ultrasound, testing, and physical examination. Early stimulation, widely acknowledged for infants and toddlers (up to 3 years of age) with multiple disabilities, was prioritized but it was unavailable to a large proportion of the children with CZVS because of lack of access to services, equipment, technologies, and trained and accredited professionals. Training of healthcare professionals proved to be strategic for achieving better results.

During the emergency, scientific evidence from previous experience and produced at the time was shared via different public and private information and communications channels. Community, group, and family involvement played an important role in producing and disseminating knowledge, contributing to pressure government to respond to the needs created by the epidemic ${ }^{68}$.

CZVS has proven to be more common than microcephaly alone, potentially affecting infants without apparent alterations in head circumference ${ }^{\mathbf{7 4}, 75}$, so that on-going follow-up of the children in this cohort is necessary. Reprogramming should focus on the growing demands for support for the mother, the child, and the person with disabilities, including: access to 'assistive technologies'76; intensive rehabilitation, including braces and prosthese ${ }^{44}$; early stimulation with a physical therapist, consultations with pediatricians, psychologists, and ophthalmologists, audiometry, and management of the children's difficulties eating and with mobility 77 ; access to income and transportation benefits; supply of caregivers; openness to these children in the school system $^{\mathbf{7 8}}$; and psychosocial support for caregivers and families ${ }^{79}$.

For the women and children affected by Zika, access to services and knowledge is marked by numerous unequal conditions that are expressed in the response and in SUS reprogramming $\mathbf{8 0 , 8 1}$. The protocols do not always acknowledge and contextualize the limitations resulting from socioeconomic inequalities, vulnerabilities, and other barriers.

In Brazil, the responses occurred in the context of a political, social, and economic crisis, suggesting the constraints on scientific and technological investment and the capacity for response and reprogramming of the Unified Health System (SUS), as well as the exacerbation of negative socioeconomic conditions in places and populations at risk. Brazil's universal health system with continental dimensions and diverse experience and actions made a difference, despite the inequalities and limitations in supply, access, financing, and different degrees of institutional implementation and political coordination. 


\section{Proposal for analysis and management of future health emergencies involving arboviral infections}

The ZIKV epidemic highlighted the importance and urgency of the health systems' response to its effects and mitigation of the risks. The analysis of health emergencies is not simple and requires exploring the existing scientific knowledge as well as the uncertainties in order to identify approaches for an effective and timely response that values the understanding and linkage between the epidemic's contexts and repercussions.

The scientific knowledge and its gaps are thus a central and integrating element in the dimensions analyzed here, highlighting the cross-cutting nature of information and communications in the analyses of emergencies related to arboviral infections. These dimensions are part of a three-dimensional and dynamic context that has a dialectic relationship with the living conditions of the population in each place and repercussions of the epidemic. Thus, the linkage between dimensions and elements should be directed to allow specific areas of research and produce possible outcomes. When these outcomes are measured, they should allow generating new knowledge and evidence on the epidemic's repercussions and the healthcare system's responses.

Health systems' analysis and management of future emergencies involving arboviral epidemics should consider, among others, the basic guidelines listed in chart 1 . This instrument integrates the dimensions analyzed here, to the extent that some of its elements are correlated, with a focus on the affected, vulnerable, and at-risk populations and places, attempting to avoid segmented and sector-limited logics to guide health policies and programs.

Chart 1. Script with basic questions for analysis and management of health emergencies involving arboviral epidemics

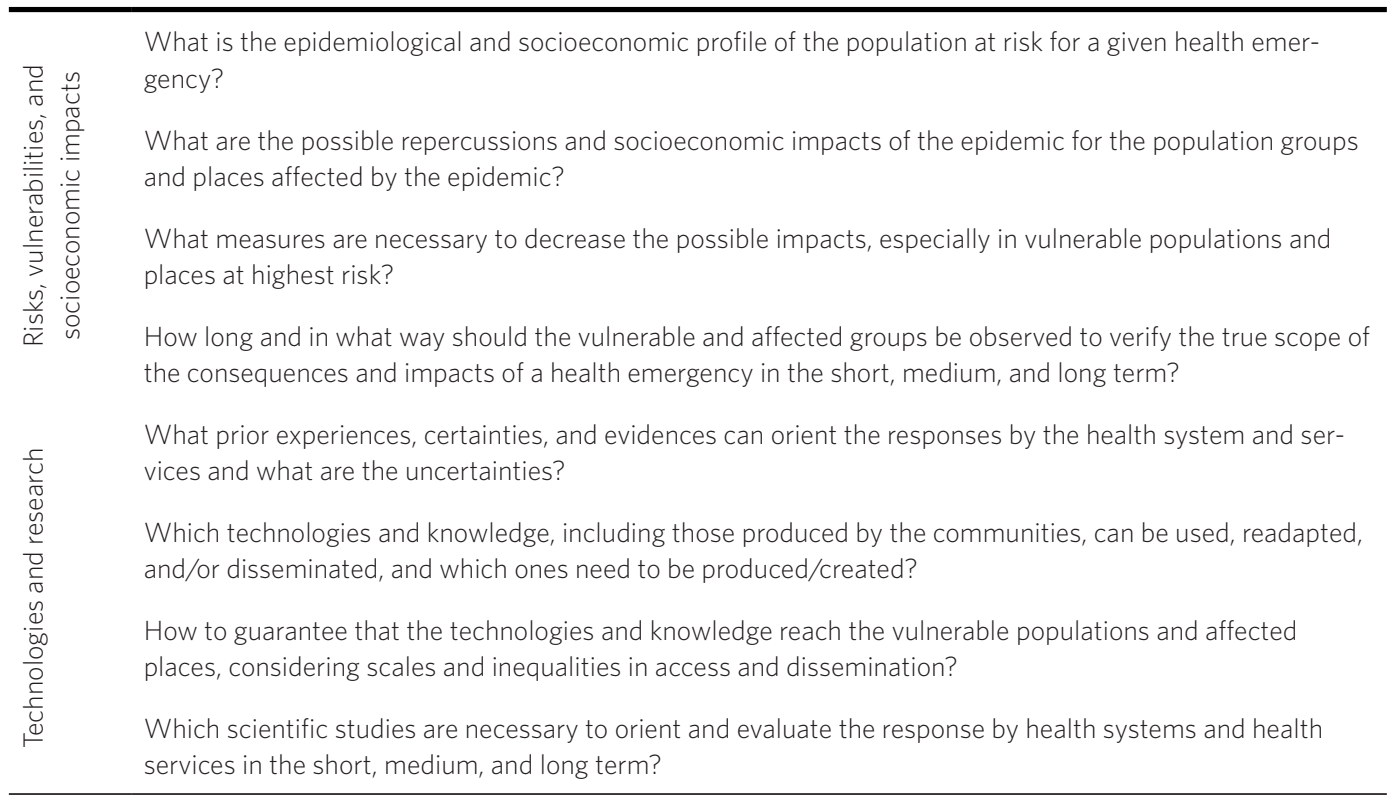


Chart 1. (cont.)

Which information, actions, resources, and protocols are necessary and should be priorities for orienting the
response by health systems and health services in the short, medium, and long term?

Source: Own ellaboration.

The study did not intend to provide a finished and complete model for public health emergencies involving arboviral infections. On the contrary, the proposal expresses the reflections on (and formulation of) some key questions, which are not exhaustive, to orient responses to future emergencies. These questions should be adapted to the different realities. The meaning of 'at risk' or 'preparedness' to confront public health emergencies involving arboviral infections varies according to country, place, and time. Figure 1 schematically illustrates the integrated analytical proposal.

Figure 1. Proposal for integrated analysis of health emergencies involving arboviral infections
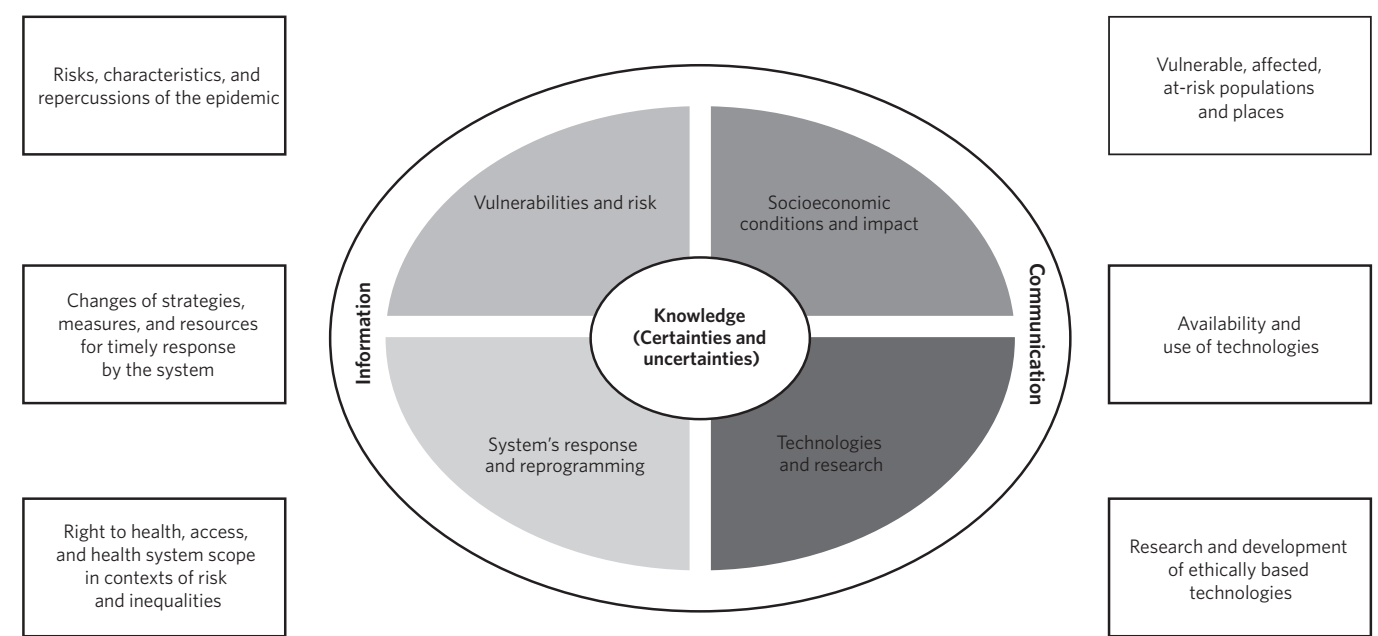

Source: Own ellaboration. 
The evidence points to the growing need for linkage between policies, involving all these dimensions, which are highly interdependent. Activation of the chain that ranges from research/development to the effects of short-, medium-, and long-term technologies, involving issues of financing, access, and use, involves the need for new mechanisms of coordination and management by government. It is necessary not only to conduct research and action, but also to acquire the capacity to evaluate their effects on the population. Emergency policies and responses should also consider the inequalities and other factors related to the affected populations, especially those in situations of vulnerability and poverty.

The new diagnostic and therapeutic technologies for arboviral infections cannot be effective without government strategies that ensure access and use by the population. Investments in the production of scientific evidence to support policies for regulation, incorporation, and use of technologies are essential in the response to public health emergencies. It is essential to interconnect strategies to reduce inequalities and improve living conditions in order to generate protective effects for the most heavily affected population groups.

Vaccines, repellents, medicines, and assistive technologies need to be available in timely fashion and associated with inter-sector activities, especially for social protection, education, and sanitation. Improvements in the population's living and socioeconomic conditions can reduce the vulnerability and the risks associated with poverty. The subsequent confirmation (in humans) of cross-reactivity to the yellow fever vaccine with protective effect will corroborate the need to maintain vaccination coverage to minimize the effects of ZIKV and other arboviral infections, especially in pregnant women in situations of vulnerability.

In Brazil, strategies that are known to be effective, such as improvements in sanitation, housing, and urban upgrading, have been relegated to a secondary place. Such measures extrapolate the health sector and require inter-sector effort, including not only vector control but also the reduction of inequalities and vulnerabilities.

The ZIKV epidemic revealed that beyond the areas that should be prioritized in the response to a health emergency, a central issue involves the different definitions of the right to health, which can represent an expansion (or curtailment) of access to services and the scope of health systems, as well as to determine how the system responds to the demands. Broad and universal health rights are not guaranteed in all countries or even equally in each country's population. However, to deal with future emergencies involving arboviral infections, an integrated approach should be based on a comprehensive view of the right to health and equity.

\section{Acknowledgments}

The authors wish to thank the members and coordinators of the project 'Social Sciences and the Humanities and the Zika Virus Epidemic in Brazil'. The research leading to the current essay is part of this project.

\section{Collaborators}

Pepe VLE (0000-0003-0606-1544)*, Albuquerque MV (0000-0002-0763-6357)*, Osorio-de-Castro CGS (0000-0003-48757216)*, Pereira CCA (0000-0003-13899214)*, Dias HS (0000-0003-3419-2496)*, and Miranda ES (0000-0002-6204-5023)* contributed to the article's conception, drafting of the manuscript, critical revision of the content, and approval of the final version. Oliveira CVS (0000-0002-0464-1476)*, Reis LGC (0000-0001-5020-2469)*, and Reis CB (0000-0002-6118-2130)* contributed to the article's conception, drafting of the manuscript, and approval of the final version.
*Orcid (Open Researcher and Contributor ID). 


\section{References}

1. Lima-Camara TN. Emerging arboviruses and public health challenges in Brazil. Rev Saúde Pública. 2016; 50(36):1-7.

2. Lopes N, Nazawa C, Linhares REC. Características gerais e epidemiologia dos arbovírus emergentes no Brasil. Rev Pan-Amaz Saude. 2014; 5(3):55-64.

3. Teixeira MG, Costa MCN, Oliveira WK, et al. The Epidemic of Zika Virus-Related Microcephaly in Brazil: Detection, Control, Etiology, and Future Scenarios. Am J Public Health. 2016; 106(4):601-5.

4. Brasil. Ministério da Saúde. Portaria $n^{\circ} 1.813$, de 11 de novembro de 2015. Declara Emergência em Saúde Pública de Importância Nacional (ESPIN) por alteração do padrão de ocorrência de microcefalias no Brasil. Diário Oficial da União. 12 Abr 2015.

5. World Health Organization. Emergency response framework. 2. ed. Geneva: WHO; 2017.

6. Gulland A. Zika virus is a global public health emergency, declares WHO. BMJ. 2016; (352):i657-i657.

7. Nunes J, Nacif Pimenta D. A epidemia de Zika e os limites da Saúde Global. Lua Nova. 2016; (98).

8. Brasil. Decreto $n^{\circ} 7.616$, de 17 de novembro de 2011. Dispõe sobre a declaração de Emergência em Saúde Pública de Importância Nacional - ESPIN e institui a Força Nacional do Sistema Único de Saúde - FN-SUS. 2011. Diário Oficial da União. 18 Nov 2011.

9. Cutter SL, Boruff BJ, Shirley WL. Social Vulnerability to Environmental Hazards. Soc Sci Q. 2003; 84(2):242-61.

10. Sheikhbardsiri H, Yarmohammadian MH, Rezaei F, et al. Rehabilitation of vulnerable groups in emergencies and disasters: A systematic review. World J Emerg Med. 2017; 8(4):253-63.

11. Fordham M, Lovekamp WE, Thomas DSK, et al. Un- derstanding Social Vulnerability. In: Thomas DSK, Phillips BD, Lovekamp WE, et al., editores. Social Vulnerability to Disasters 2. ed. Boca Raton: CRC Press; 2013.

12. Possas C, Brasil P, Marzochi MC, et al. Zika puzzle in Brazil: peculiar conditions of viral introduction and dissemination - A Review. Mem Inst Oswaldo Cruz. 2017; 112(5):319-27.

13. Brasil. Ministério da Saúde. Boletim Epidemiológico - Sífilis. 2015; 4(1):1-32.

14. Brasil. Ministério da Saúde. Sarampo - Situação Epidemiológica/Dados [internet]. [acesso em 2019 mar 3]. Disponível em: http://www.saude.gov.br/saude-de-a-z/sarampo/situacao-epidemiologica-dados.

15. Brasil. Ministério da Saúde. Boletim Epidemiológico. Monitoramento dos casos de dengue até a semana epidemiológica (SE) 38 e febre de chikungunya até a SE 39 de 2014. 2015; 45(23):1-6.

16. Ferguson NM, Cucunubá ZM, Dorigatti I, et al. EPIDEMIOLOGY. Countering the Zika epidemic in Latin America. Science. 2016; 353(6297):353-4

17. Osorio-de-Castro CGS, Miranda ES, Freitas CM, et al. The Zika Virus Outbreak in Brazil: Knowledge Gaps and Challenges for Risk Reduction. Am J Public Health. 2017; 107(6):960-5.

18. Albuquerque MFPM, Souza WV, Araújo TVB, et al. Epidemia de microcefalia e vírus Zika: a construção do conhecimento em epidemiologia. Cad. Saúde Pública. 2018; 34(10):e00069018

19. Rego S, Palácios M. Ethics, global health and Zika virus infection: a view from Brazil. Rev Bioét. 2016; 24(3):430-4.

20. Haire B. Aspects of disaster research ethics applicable to other contexts. J Med Ethics. 2018; 44(1):9. 
21. Santos BMC, Coelho FC, Armstrong M, et al. Zika: an ongoing threat to women and infants. Cad. Saúde Pública. 2018; 34(11).

22. Rasmussen SA, Jamieson DJ, Honein MA, et al. Zika Virus and Birth Defects - Reviewing the Evidence for Causality. N Engl J Med. 2016; 374(20):1981-7.

23. Brasil. Ministério da Saúde. Ministério da Saúde confirma relação entre vírus Zika e microcefalia. 2015.

24. Essue B, Laba T, Knaul F, et al. Economic Burden of Chronic Ill Health and Injuries for Households in Low - and Middle-Income Countries. In: Jamison DT, Gelband H, Jha PK, et al. Disease Control Priorities: Improving Health and Reducing Poverty. 3. ed. Washington (DC): The World Bank; 2017.

25. Kankeu HT, Saksena P, Xu K, et al. The financial burden from non-communicable diseases in low- and middle-income countries: a literature review. Health Res Policy Syst. 2013; 11(31):1-8.

26. McIntyre D, Thiede M, Dahlgren G, et al. What are the economic consequences for households of illness and of paying for health care in low- and middle-income country contexts? Soc Sci Med. 2006; 62(4):858-65.

27. World Health Organization. WHO guide to identifying the economic consequences of disease and injury. Geneva: WHO; 2009.

28. Oliveira SJGS, Melo ES, Reinheimer DM, et al. Anxiety, depression, and quality of life in mothers of newborns with microcephaly and presumed congenital Zika virus infection. Arch Womens Ment Health. 2016; 19(6):1149-51.

29. Knaul FM. Household spending and impoverishment. Cambridge: Harvard University Press; 2012.

30. Organisation for Economic Co-operation and Development. Sickness, disability and work: breaking the barriers ; a synthesis of findings across OECD countries. Paris: OECD; 2010.
31. Brasil. Presidência da República. Lei no 8.069, de 13 de julho de 1990. Dispõe sobre o Estatuto da Criança e do Adolescente e dá outras providências. Diário Oficial da União. 14 Jul 1990.

32. Fundo das Nações Unidas para a Infância. Children with disabilities. New York: UNICEF; 2013.

33. Organisation for Economic Co-operation and Development. Equity and Quality in Education: Supporting Disadvantaged Students and Schools. Paris: OECD; 2012.

34. Drummond M. Methods for the economic evaluation of health care programmes. 4. ed. Oxford; New York: Oxford University Press; 2015.

35. Syed ST, Gerber BS, Sharp LK. Traveling Towards Disease: Transportation Barriers to Health Care Access. J Community Health. 2013; 38(5):976-93.

36. Bredenkamp C, Mendola M, Gragnolati M. Catastrophic and impoverishing effects of health expenditure: new evidence from the Western Balkans. Health Policy Plan. 2011; 26(4):349-56.

37. Programa das Nações Unidas para o Desenvolvimento. Uma avaliação do impacto socioeconômico do vírus Zika na América Latina e Caribe: Brasil, Colômbia e Suriname como estudos de caso. Nova York: PNDU; 2017.

38. Counotte M, Egli-Gany D, Riesen M, et al. Zika virus infection as a cause of congenital brain abnormalities and Guillain-Barré syndrome: From systematic review to living systematic review. F1000Research. 2018; 7(196):1-20.

39. Garcia LP. Epidemia do vírus Zika e microcefalia no Brasil: emergência, evolução e enfrentamento - Texto para Discussão. Brasília, DF: IPEA; 2018.

40. Garcia LP, Duarte E. Evidências da vigilância epidemiológica para o avanço do conhecimento sobre a epidemia do vírus Zika. Epidemiol Serv Saúde. 2016; 25(4):679-81. 
41. Zara LSA, Santos SM, Fernandes-Oliveira SE, et al. Estratégias de controle do Aedes aegypti: uma revisão. Epidemiol E Serviços Saúde. 2016; 25(2):1-2.

42. Wilder-Smith A, Gubler DJ, Weaver SC, et al. Epidemic arboviral diseases: priorities for research and public health. Lancet Infect Dis. 2017; 17(3):e101-6.

43. Spedo SM, Pinto NRS, Tanaka OY. O difícil acesso a serviços de média complexidade do SUS: o caso da cidade de São Paulo, Brasil. Physis. 2010; 20(3):95372 .

44. Reis LGC. Comentário sobre o artigo de Eickmann. Cad. Saúde Pública. 2016; 32(7):eC0010716.

45. Barreto ML, Barral-Netto M, Stabeli R, et al. Zika virus and microcephaly in Brazil: a scientific agenda. Lancet. 2016; 387(10022):919-21.

46. Vanni T, Chalegre KD, Giaretta Sachetti C, et al. Zika virus emergency in Brazil: scientific challenges and early developments. F1000Research. 2016; (5):1915.

47. Santos ACV, Guedes-da-Silva FH, Dumard CH, et al. Yellow Fever Vaccine Protects Resistant and Susceptible Mice Against Zika Virus Infection. BioRxi. 2019; 1-32.

48. Chen Q, Wu J, Ye Q, et al. Treatment of Human Glioblastoma with a Live Attenuated Zika Virus Vaccine Candidate. mBio. 2018; 9(5):e01683-18.

49. Lowe R, Barcellos C, Brasil P, et al. The Zika Virus Epidemic in Brazil: From Discovery to Future Implications. Int J Environ Res Public Health. 2018; 15(1):96

50. Tavares M, Silva MRM, Oliveira de Siqueira LB, et al. Trends in insect repellent formulations: A review. Int J Pharm. 2018; 539(1-2):190-209.

51. Bowman NM, Akialis K, Cave G, et al. Pyrethroid insecticides maintain repellent effect on knock-down resistant populations of Aedes aegypti mosquitoes. PLoS One. 2018; 13(5):e0196410
52. Mesci P, Macia A, Moore SM, et al. Blocking Zika virus vertical transmission. Sci Rep. 2018; 8(1):1218.

53. Snyder B, Goebel S, Koide F, et al. Synergistic antiviral activity of Sofosbuvir and type-I interferons ( \&\#945; and ß) against Zika virus. J Med Virol. 2018; 90(1):812 .

54. Li Z, Sakamuru S, Huang R, et al. Erythrosin B is a potent and broad-spectrum orthosteric inhibitor of the flavivirus NS2B-NS3 protease. Antivir Res. 2018; (150):217-25.

55. Shiryaev SA, Mesci P, Pinto A, et al. Repurposing of the anti-malaria drug chloroquine for Zika Virus treatment and prophylaxis. Sci Rep. 2017; 7(1):15771.

56. Moreira TMM, Pinheiro JAM, Florencio RS, et al., organizadores. Tecnologias para a promoção e o cuidado em saúde. Fortaleza: EdUECE; 2018.

57. Ventura DFL. Do Ebola ao Zika: as emergências internacionais e a securitização da saúde global. Cad. Saúde Pública. 2016; 32(4): e00033316.

58. World Health Organization. Zika Strategic Response Framework \& Joint Operations Plan. January-June 2016. Genova: WHO; 2016.

59. Wenham C, Farias DB. Securitizing Zika: The case of Brazil. Secur Dialogue. 2019; 50(5):398-415

60. Brasil. Ministério da Saúde. Vírus Zika no Brasil. A resposta do SUS. Brasília, DF: MS; 2017.

61. D’Agostino M, Samuel NO, Sarol MJ, et al. Open data and public health. Rev Panam Salud Pública. 2018; (42):1-8.

62. Pavão ALB, Barcellos C, Pedroso M, et al. The role of Brazilian National Health Information Systems in assessing the impact of Zika virus outbreak. Rev Soc Bras Med Trop. 2017; 50(4):450-7.

63. Ndeffo-Mbah ML, Parpia AS, Galvani AP. Mitigating Prenatal Zika Virus Infection in the Americas. Ann Intern Med. 2016; 165(8):551. 
64. Kroelinger CD, Romero L, Lathrop E, et al. Meeting Summary: State and Local Implementation Strategies for Increasing Access to Contraception During Zika Preparedness and Response - United States, September 2016. Morb Mortal Wkly Rep. 2017; 66(44):12305.

65. Lathrop E, Romero L, Hurst S, et al. The Zika Contraception Access Network: a feasibility programme to increase access to contraception in Puerto Rico during the 2016-17 Zika virus outbreak. Lancet Public Health. 2018; 3(2):e91-9.

66. Ali M, Miller K, Gómez Ponce de Leon RF. Family planning and Zika virus: need for renewed and cohesive efforts to ensure availability of intrauterine contraception in Latin America and the Caribbean. Eur J Contracept Reprod Health Care. 2017; 22(2):102-6.

67. González Vélez AC, Diniz SG. Inequality. Zika epidemics, and the lack of reproductive rights in Latin America. Reprod Health Matters. 2016; 24(48):57-61.

68. Baum P, Fiastro A, Kunselman S, et al. Ensuring a rights-based health sector response to women affected by Zika. Cad. Saúde Pública. 2016; 32(5): e00064416.

69. Lesser J, Kitron U. A geografia social do Zika no Brasil. Estud Avancados. 2016; 30(88):167-75.

70. Valente PK. Zika and Reproductive Rights in Brazil: Challenge to the Right to Health. Am J Public Health. 2017; 107(9):1376-80.

71. Tavares MP, Foster AM. Emergency contraception in a public health emergency: exploring pharmacy availability in Brazil. Contraception. 2016; 94(2):109-14.

72. Ravi SJ. Strengthening Health Systems Through International Blood Product Sharing Agreements. Health Secur. 2017; 15(1):110-7.

73. Bloch EM, Ness PM, Tobian AAR, et al. Revisiting Blood Safety Practices Given Emerging Data about Zika Virus. N Engl J Med. 2018; 378(19):1837-41.
74. Moreira MCN, Nascimento M, Mendes CHF, et al. Emergency and permanence of the Zika virus epidemic: an agenda connecting research and policy. Cad. Saúde Pública. 2018; 34(8): e00075718.

75. Einspieler C, Utsch F, Brasil P, et al. Association of Infants Exposed to Prenatal Zika Virus Infection With Their Clinical, Neurologic, and Developmental Status Evaluated via the General Movement Assessment Tool. JAMA Netw Open. 2019; 2(1):e187235.

76. Sá FE, Andrade MMG, Nogueira EMC, et al. Produção de sentidos parentais no cuidado de crianças com microcefalia por vírus zika. Rev Bras Em Promoção Saúde. 2017; 30(4):1-10.

77. Diniz D. Vírus Zika e mulheres. Cad. Saúde Pública. 2016; 32(5): e00046316.

78. Brasil. Ministério da Saúde, Fundação Oswaldo Cruz, Instituto Fernandes Figueira. Guia prático de direitos para profissionais de saúde e famílias de crianças com a síndrome congênita do Zika vírus no Rio de Janeiro. Rio de Janeiro: MS; Fiocruz; IFF; 2019.

79. Freire IM, Pone SM, Ribeiro MC, et al. Síndrome congênita do Zika vírus em lactentes: repercussões na promoção da saúde mental das famílias. Cad. Saúde Pública. 2018; 34(9):e00176217.

80. Brunoni D, Blascovi-Assis SM, Osório AAC, et al. Microcephaly and other Zika virus related events: The impact on children, families and health teams. Ciênc. Saúde Colet. 2016; 21(10):3297-302.

81. Morain SR, Wootton SH, Eppes C. A Devastating Delay - Zika and the Implementation Gap. N Engl J Med. 2017; 377(16):1505-7.

Received on 07/10/2019

Approved on 02/18/2020

Conflict of interests: non-existent

Financial support: European Union's Horizon 2020 Research and

Innovation Programme under ZIKAlliance Grant Agreement no

734548 